\title{
Domestic Violence in South Africa: Women and Children Under Siege?
}

\author{
Neo Morei \\ Senior Lecturer, Faculty of Law, North West University \\ Email:neo.morei@nwu.ac.za
}

\section{Doi:10.5901/mjss.2014.v5n20p928}

\section{Abstract}

Domestic violence is rife in South Africa and it has harsh effects on the society, particularly on family life. It cuts across class, race, culture and geography and it is all the more pernicious because it is often concealed and so frequently goes unpunished. The most vulnerable in our communities, women, children and the elderly all live in fear, simple things like walking one's dog or jogging early in the morning or late in the afternoon can turn tragic. It seems there are few places for South African women and children to be safe. The existing legislative framework aimed at combating domestic violence seems to be unable to effectively address issues of domestic violence in the Republic (Domestic Violence Act). It is therefore, the purpose of this paper to give an overview of domestic violence legislation in South Africa and determine whether government has fulfilled its constitutional mandate in the protection of women and children. Some recommendations are made.

Keywords: Domestic violence, women, children, legislation, South Africa

\section{Introduction}

While the Minister of Police Mr Nathi Mthetwa assures South Africans that, on average, crime has decreased and the murder rate has dropped by $6.5 \%$, this does not seem to be the case with women and children given some of the happenings in the past year or so' ${ }^{1}$ There is no reliable measure for domestic violence because it is not a crime category in its own right when it comes to reporting with the result that one has nothing more than reports in the media. The statistics do not include cases of domestic violence because domestic violence remains a crime which is not included in South African Police Services annual crime statistics. Sometimes cases of domestic violence are not even reported to the police for fear of intimidation, shame, fear of not being believed, self-blame, or fear of retaliation. There are many actions that constitute's domestic violence that are not defined as crimes, such as forced isolation, verbal abuse, stalking and economic abuse. ${ }^{2}$ Domestic violence is often not just a one-off event, but a series of events, or a continuous pattern of abuse. ${ }^{3}$ Although these crimes decreased by 6.6 percent, the reduction does not necessarily mean that there are fewer assaults taking place. ${ }^{4}$

It is estimated that a woman is killed by her male partner every six hours, the highest rate of death by domestic violence in the world. ${ }^{5}$ The killing of Reeva Steenkamp by her Olympian Gold Medalist boyfriend Oscar Pistorius, Anene Booysen's rape and murder in a small town of Bredasdorp, Thandiswa Qubuda of Hlahani in Grahamstown was raped, beaten and died after lying brain dead in hospital for six weeks, Ivy Molefe's murder by her husband and three others, Molefe's husband reported her missing after she did not return from work at a provincial finance department on March 4, 2012. The four were arrested in April 2012before one of the suspects made a confession and pointed out where Molefe's body had been hidden. On November 12, 2013 a prominent Pietermaritzburg doctor had to crawl to seek help early on Monday morning after being dragged into the bush and raped in upmarket Clarendon. She had been out jogging and had stopped to ties her shoelace, when she was grabbed by her neck and dragged into the nearby bushes. These are just a few examples of cases that made headline news.

My suspicion is that, there might be many horrific incidents of violent crime in South Africa that are never reported nor receive media coverage. Children are also not spared. Recently, the nation was shocked with the discovery of two

\footnotetext{
${ }^{1}$ Factsheet South Africa; Official Crime Statistics for 2012/13 Available: https://africacheck.org/...factsheet-South Africa-officialcrime-statistics-f.,http://www.news24.com/SouthAfrica /News/FACTSHEET-SAs-2012/13-crime-statistics (October 22, 2013)

2 Diessel, A., \& Ngubeni K. Giving Women their Voice: Domestic Violence and Restorative Justice in South Africa available : http://csvr.org.za/docs/crime/givingwomenvoice.pdf. (October 20, 2013)

3 Ibid.

4 Ibid.

5 Freeman, C. Four women killed by their partners every day in South Africa available: http://www.thesouthafrican.com/news/four-women-killed-by-their-partners-every-day (20,October/2013)
} 
toddler bodies in a communal toilet in Diepsloot informal settlement, South of Johannesburg. The girls had been reported missing several days earlier. The suspects were arrested and confessed to the killings. Many women in South Africa are unwilling or unable to confront the violence that has occurred against them, there are few places to turn for help. If safe places exist, they are few and far apart, police officers are often not adequately trained to deal with serious psychological damage that domestic violence and rape can breed.

From early in their lives, South African men are exposed to institutions and relationships that place females below their male counterparts. Most African cultures are infused with patriarchal practices. Men regard women as their possessions that they can control and maintain. This behavoiur is cultural, something that the police do not understand. ${ }^{6}$ It is submitted that although South African society has moved from the culture of traditional gender roles and relationships, the country still adheres to archaic norms. Men have always felt the need to assert their masculinity over women.

There could be and there, probably are a lot of reasons for the inability of South Africa to contain domestic violence. However, this paper seeks to focus only on the role of the law in dealing with the problem. It is, therefore, the purpose of this paper to give an overview of domestic violence legislation and the role of law enforcement agencies in dealing with domestic violence cases. The state incurs obligations in terms of the Bill of Rights which guarantees the right to equality and to freedom and security of all people. Domestic violence offends the values and rights enshrined in the Constitution. ${ }^{7}$

According to section (1) non-sexism is a founding value of our state. In addition, human dignity, the achievement of equality and the advancement of human rights and freedoms are recognized as founding values. Section 12(1) (c) provides that everyone has the right to freedom and security of the person, which includes the right to be free from all forms of violence from public or private sources. This right must be understood in conjunction with the rights to dignity, life, equality and privacy. South Africa is also a signatory to various conventions of the United Nations, including the Convention on the Elimination of all Forms of Discrimination against Women ${ }^{8}$ and the Convention on the Rights of the Child. ${ }^{9}$ In terms of these conventions the Republic incurred obligations towards the protection of women and children. A determination will also be made on whether government is taking necessary steps to ensure compliance with international conventions that condemn violence against women Furthermore, a determination on whether domestic violence legislation is effective in its implementation, the response of the criminal justice system and possible lasting solutions will be explored.

In conclusion, it will be submitted that although the Domestic Violence Act exhaustively and comprehensively expounds on what domestic violence is, gives detailed strategies on how state departments should address domestic violence, the Act fails to provide strategies that take into consideration cultural, social and economic factors as the forces within which domestic violence is embedded. The Act to a certain extend has not benefitted the people it was intended to protect, state resources have been wasted in ensuring its effective implementation. It will also be submitted, in conclusion, that it is not only about the ineffectiveness of the existing legislation nor lack of skills on part of enforcement agencies but the challenge is with the embedded social, cultural and economic inequality of South African society.

\section{An Overview of Domestic Violence Legislation}

\subsection{The Constitution}

Violence against women and children violates a number of provisions in South Africa's Constitution ${ }^{10}$ (hereafter referred to as "the Constitution"). Section 12 of the Constitution ${ }^{11}$ combines the right to freedom and security of the person with a right to bodily and psychological integrity. ${ }^{12}$ This right is an innovation in the Bill of Rights in that it is modelled on article $5^{13}$ of the International Convention on the Elimination of All Forms of Racial Discrimination. ${ }^{14}$ Violence against individuals is a grave invasion of personal security. Section 12(1) (c) requires the state to protect individuals, both negatively by

\footnotetext{
6 Mshungane M: Domestic violence Under Indigenous Law Any Remedies?

7 Constitution of the Republic of South Africa, 1996.

${ }^{8}$ Adopted on 18 December 1979, G.A.Res 34/180, U.N GAOR, 34th Sess. Supp. No. 46, U.N.Doc. A/34/46 (1980). Although CEDAW does not contain an article dealing with domestic violence per se, domestic violence is specifically addressed in the following General Recommendations viz: General Recommendation 12, Violence Against Women adopted 3 March 1989 U.N.Doc. A/44/38 (1990); General Recommendation 19, Violence Against Women adopted 30 January 1992 U.N. Doc.A47/38 (1993).

9 Ratified by South Africa on 20 November 1995.

10 The Constitution of the Republic of South Africa, 1996.

11 lbid.

12 Currie, I. \& De Waal, J. (2005) The Bill of Rights Handbook $5^{\text {th }}$ ed Juta Cape Town 292.

${ }^{13}$ Art 5 (b) refers in particular to the right to security of the person and protection by the State against violence or bodily harm, whether inflicted by government officials or by any individual, group or institution.

14 South Africa ratified the Convention on $5^{\text {th }}$ December 1995.
} 
refraining from such invasions itself and positively by restraining or discouraging private individuals from such invasions. ${ }^{15}$

The right to be free from all forms of violence from either public or private sources clearly operates both vertically and horizontally. On the vertical level, those affected by the state's power to use force (for example, when breaking up demonstrations), are certain to rely on the right to be free from violence. ${ }^{16}$ On the horizontal level, the right imposes an obligation on the state to prevent violent acts by individuals against others. ${ }^{17}$ In essence, the section protects an individual's physical integrity against invasion from public and private sources. In Sv Baloyili the Constitutional Court pointed out that specific inclusion of private sources emphasize that serious threats to security of a person arise from those sources. ${ }^{19}$ Judge Sachs indicated that, read with section 7(2) of the Constitution (which obliges the state to protect, respect, promote and fulfill the rights in the Bill of Rights), section 12(1) obliges the state to protect everyone's right to be free from private or domestic violence..$^{20}$ The right to bodily and psychological integrity, the right to dignity, the right not to be tortured in any way, and the right not to be treated or punished in a cruel, inhuman or derogatory way also oblige the state to deal with domestic violence.

Basically what happened in Baloyi's case is that, ${ }^{21}$ the complainant had laid a charge of assault against the appellant, her husband, and successfully applied for an interdict in terms of the Prevention of Family Violence Act. ${ }^{22}$ The interdict prohibited the appellant from assaulting the complainant and their child and from preventing them from leaving and entering their joint home. A suspended warrant of arrest of the appellant was simultaneously granted in terms of the Act. In breach of the interdict, the appellant assaulted the complainant again and threatened to kill her. When she reported this to the police, the appellant was arrested and brought before a magistrate for an enquiry. He was convicted of violating the interdict and sentenced to 12 months imprisonment, with six suspended.

He successfully appealed to the Pretoria High Court, contending that section 3(5) of the Family Violence Act ${ }^{23}$ imposed an onus on him to prove that he had not willfully violated the interdict and the provision was therefore unconstitutional. After declaring section 3(5) of the Act invalid, the court referred its decision to the Constitutional Court for confirmation. The Constitutional Court declined to confirm the order of invalidity and held that the section did not create a reverse onus and did not affect the presumption of innocence of an accused person. The Court noted the ineffectiveness of the criminal justice system in addressing family violence which intensifies the subordination and helplessness of the victims as well as the role of the State in protecting women from private or domestic violence. The matter was referred back to the High Court to be dealt with in accordance with the Constitutional Court's decision.

In Carmichele v Minister of Safety and Security and Another ${ }^{24}$ the Court upheld an application by a woman to have the Minister of Justice and the Minister of Safety and Security held liable for her brutal attack by a man, who at the time, was awaiting trial for having attempted to rape another woman and who had been released on the recommendation of the investigation officer and prosecutor, without bail, despite his history of sexual violence. The Court held that the state is obliged by the Constitution and international law to prevent violence against women which is a form of gender discrimination and to protect the dignity, freedom and security of women. ${ }^{25}$ It also held that the courts had the duty to develop the common law to make provision for holding the state accountable. When the matter went back to the High Court, the state was found liable and ordered to pay a specified amount.

This case constitutes a major breakthrough for victim's rights and the fight to end violence against women. Violence against women is a form of gender based discrimination as envisaged in international law and the state has a duty to prevent it; The Constitutional Court considered the potential liability of both the police and prosecutors. It held that the State is obliged by the Constitution and international law to prevent gender-based discrimination and to protect the dignity, freedom and security of women. The Court further held that the police service:

"is one of the primary agencies of the State responsible for the protection of the public in general and women and children in particular against the invasion of their fundamental rights by perpetrators of violent crimes."26

\footnotetext{
${ }^{15}$ De Waal \& Currie op cit $n 12304$.

${ }_{16}$ Currie, I. \& De Waal, J. et al (2005) The New Constitutional \& Administrative Law vol 1 Juta Cape Town 366.

17 Ibid.

182000 (1) BCLR 86 (CC), 2000 (2) SA 425 (CC); 2000 (1) SACR 81 (CC).

${ }_{19}$ De Waal \& Currie op cit $n 16$ p 253.

20 Ibid.

212000 (2) SA 425 (CC); 2000 (1) BCLR 86 (CC).

22133 of 1993

23 Ibid.

242001 (4) SA CC; 2001 (10) BCLR 995 CC.

25. Ibid at $n 24$ The Court referred to the Convention on the Elimination of all forms of Discrimination Against Women (CEDAW), adopted by the United Nations in General Assembly Resolution 34/180 on 18 December 1979, and signed on January 1993 and ratified by South Africa on 15 December 1995, as well as the recommendations of the Committee on the Elimination of Discrimination Against Women. Articles 2, 3, 6, 11,12 and 16 of CEDAW directly or indirectly relate to violence against women. The principles of CEDAW are also evident in the Preamble of the Universal Declaration of Human rights adopted on 10 December 1948 and Article 4(d) of the Declaration on the Elimination of Violence Against Women of 1994 .

26 At para 62.
} 
Damages may be claimed against the state, in appropriate circumstances, when it fails to honor its duty to protect women against violence.

The same sentiments were expressed by the European court in the case of Opuz $v$ Turkey ${ }^{27}$ which concerns the issue of domestic violence carried out on the applicant and her mother, which resulted in the murder of the applicant's mother and persistent threats on the life of the applicant. ${ }^{28}$ The European Court held that there had been a violation of article 2 of the Convention in respect of the death of the applicant's mother, a violation of Art 3 of the Convention in respect of authorities failure to protect the applicant against domestic violence perpetrated by $\mathrm{HO}$ and that there has been a violation of Art 14 read in conjunction with Arts 2 and 3 of the Convention. ${ }^{29}$ In reaching a decision in this case, the Court referred to CEDAW, CEDAW Committee's General Recommendation No 9 on Violence Against Women' which found that that gender-based violence is a form of discrimination that seriously inhibits women's ability to enjoy rights and freedoms on a basis of equality with men' which is prohibited under Art 1 of CEDAW. ${ }^{30}$ It was emphasized by the Court that gender-based violence triggers duties in states, including a duty on states to take all legal and other measures that are necessary to provide effective protection of women against gender-based violence including penal sanctions, civil remedies and compensatory provisions to protect women against all kinds of violence. ${ }^{31}$

In Van Eeden v Minister of Safety and Security (Women's Legal Centre Trust as Amicus Curiae) $)^{32}$ The Court upheld an appeal by a young woman (appellant) who sought damages from the state (respondent). Her action was based on the state's breach of its duty of care towards her, following her sexual assault, rape, and robbery by an unknown dangerous criminal who had escaped from police custody. The court held that it was the duty of the state to protect people against violent crime and that the police had a duty of care towards the victim. The court further held that the state was obliged to protect individuals by taking active steps to prevent violations of the constitutional right to freedom and security of the person. The court also held that the State was obliged by international law to protect women against violent crime in the light of these imperatives a special relationship between the plaintiff and the defendant was not required for the duty of care to exist. The court declared that the conduct of the police was wrongful and the state (as employer of the police) was liable to the plaintiff for such damages that she was able to prove.

In $S$ v Chapman ${ }^{33}$ involved an appeal against convictions for three counts of rape by a Magistrates' Court and the resultant sentences of seven years imprisonment in respect of each count. Chapman appealed against the convictions and sentences to a full bench of the Cape Provincial Division which dismissed the appeal. He then proceeded to the SCA where his appeal was dismissed. The SCA held that rape constituted a humiliating, degrading and brutal invasion of the privacy, the dignity and the person of the victim and that women were entitled to the protection of these rights which were basic to the ethos of the Constitution and to any defensible civilization. The court went on to categorically point out that women in this county "have a legitimate claim to walk peacefully on the streets, to enjoy their shopping and their entertainment, to go and come from work, to enjoy the peace and tranquility of their homes without fear, the apprehension and the security which constantly diminishes the quality and

enjoyment of their lives." ${ }^{34}$

In Narodien $v$ Andrews ${ }^{35}$ the Cape High Court held that the magistrate's court was not competent to make an order, under the Domestic Violence Act, ${ }^{36}$ granting visitation rights to a parent unless such order was ancillary to a domestic violence protection. The court proceeded to declare invalid an order and a variation order granting a father visitation rights under domestic Violence Act. The father had asked a magistrate court to find that a denial of his visitation rights constituted domestic violence as envisaged under the Act and had been granted visitation rights unaccompanied by a protection order. It is clear from this decision that the courts accept a broad definition of domestic violence. It is submitted that from the above discussion of the cases, it very clear that courts gave due regard to the constitutional mandate to protect the rights of women and children.

\footnotetext{
272009 App no 33401/02, 9 September 2009.

${ }_{28}$ O'Callaghan, E. (2011) Council of Europe: Case-Law of the European Court of Human Rights The International Survey of Family Law, 19

29 Ibid $p 20$

30 Ibid.

${ }^{31} \mathrm{lbid}$.

322003 (1) SA 389 (SCA).

331997 (3) SA 341 (SCA).

$34 \mathrm{lbid}$.

352002 (3) SA 500 (C)

36116 of 1998 .
} 


\subsection{Prevention of Family Violence Act ${ }^{37}$}

Prevention of Family Violence Act ${ }^{38}$ is the first legislation to specifically address domestic violence in South Africa. The Act ${ }^{39}$ allowed for parties to a civil, customary or common law marriage, fearing violence from their partner, to seek an interdict in the Magistrate's Courts. ${ }^{40}$ At the time an interdict was granted a conditional warrant of arrest was also issued for the respondent's arrest. ${ }^{41}$ In case of breach of the interdict, the applicant had to file an affidavit at the police station, enabling the police to execute the warrant and arrest the respondent. ${ }^{42}$ The respondent could then be placed in custody and be brought before the Magistrate for sentencing within 24 hours. ${ }^{43}$

Although the Act created a sui generis statutory interdict by means of which a perpetrator could be prohibited from committing domestic violence, it was criticized inter alia for being too limited in scope and for being procedurally unsound. ${ }^{44}$ Only parties to a marriage could bring an application for an interdict under the Act. ${ }^{45}$ The Act basically restricted this to a class 'a man and woman' either married according to law or custom or who have lived in a de facto relationship. Same-sex couples, couples who have been intimately involved but have never lived together, parents and to some extent, children were excluded from the ambit of this piece of legislation. ${ }^{46}$ Violence within the domestic context, the family and close family relationships therefore was not addressed comprehensively by this Act. ${ }^{47}$ The Act also failed to precisely mention most of the conducts which constitute violation of the Act. According to Kruger ${ }^{48}$ the common law and the statutory remedies available to the victims of domestic violence were not effective. In an attempt to provide better legal remedies, the whole 1993 Act, except sections 4 and 5, was repealed and replaced by the Domestic Violence Act which came into operation on 15 December 1999.

\subsection{Domestic Violence Act ${ }^{49}$}

The purpose of this Act is to afford victims of domestic violence the maximum protection from domestic abuse that the law can provide; and introduce measures which seek to ensure that relevant organs of state give full effect to the provisions of this Act, and thereby convey the message that the State is committed to the elimination of domestic violence. ${ }^{50}$ The key innovation of this Act is its broad definition of domestic violence which includes a range of behaviors within its ambit. ${ }^{51}$ Acts constituting domestic violence include physical, sexual, emotional, verbal and psychological abuse; ${ }^{52}$ economic abuse $;{ }^{53}$ intimidation; ${ }^{54}$ harassment; 55 stalking; ${ }^{56}$ damage to property; $;{ }^{57}$ entry into the complainant's residence without consent; 58 any other controlling or abusive behavior towards a complainant. ${ }^{59}$

\footnotetext{
37133 of 1993 .

$38 \mathrm{Ibid}$

39 Ibid.

40 Section 3.

41 Section 2(2).

42 Novitz, T. (1996). The Prevention of Family Violence Act 1993, Law, Race and Gender Research Unit, University of Cape Town p 1.

${ }^{43} \mathrm{lbid}$.

44 Cronje, D.S.P., \& Heaton, J. (2004) South African Family Law $2^{\text {nd }}$ ed Butterworths $p 243$.

45 Section 2.

46 Novitz op cit $n 42$ p 26.

47 Ibid.

48 Kruger, H.B. (2004) vol 29(1). Addressing Domestic Violence: To what extent does the law provide effective measures Journal of Juridical Science pp.152 -173.

49116 of 1998.

50 Preamble to the Domestic Violence Act.

51 Vetten, L. Addressing domestic violence in South Africa: Reflections on strategy and practice available: http://www.un.org/ womenwatch/daw/egm/vam-gp2005/docs/experts/vetten.vaw.pd. (28 October 2013)

52 Physical abuse refers to any act of physical or threatened act of physical violence towards a complainant; sexual abuse means any conduct that abuses, humiliates, degrades or otherwise violates the sexual integrity of the complainant; emotional, verbal and psychological abuse consists in a pattern of humiliating and degrading conduct towards a complainant, and it includes: repeated insults, ridicule, or name calling; repeated threats to cause emotional pain; repeated obsessive, possessive or jealous behavior that is a serious invasion of the complainant's privacy, freedom and security. Available http://ccjukzn.ac.za.libraries/pdf-files/Domestic-Violence Act-E (220ctober2013)

53 This includes unreasonably depriving a complainant of economic or financial resources that a complainant has a right to, in law; unreasonably depriving a complainant of economic or financial resources that complainant needs or must have; unreasonably depriving a complainant of household necessities, mortgage bond repayments or payments or payment of rent if the parties are living together; unreasonable disposal (sale/giving away) of household goods or other property in which the complainant has an interest.(Ibid $n$ 13).

${ }^{54}$ This means threatening a complainant and causing the complainant to be afraid; this includes speaking the threat, conveying (as a message) or causing a complainant to receive the threat. (Ibid $n$ 13).

${ }_{55}$ Behaving in a way that makes a complainant feel afraid of being harmed and this includes; repeated watching or loitering outside or near the building or place where the complainant lives or works, carries on business or happens to be; repeatedly making telephone calls to the complainant, or getting someone else to make such telephone calls to the complainant; this is an act of domestic violence even if there is no conversation; repeatedly sending packages, faxes, electronic post (email), or any other objects to the complainant.(Ibid $n$ 13)

56 This means repeatedly following, pursuing, or accosting the complainant.(Ibid $n$ 13)

57 Willful/intentional damage to, or destruction of, the property belonging to the complainant by the respondent; this includes property in which the complainant has a vested interest.

58 Where the complainant and the respondent do not share the same residence.

59 This means conduct that harms, or that may cause imminent harm, to safety, health or wellbeing of the complainant.
} 


\subsubsection{Application of the Act60}

The Act covers a wide range of familial ${ }^{61}$ and domestic relationships ${ }^{62}$ and covers both heterosexual and same sex relationships ${ }^{63}$ In terms of the Act the victim of domestic violence may in a prescribed manner apply to the court for a protection order ${ }^{64} \mathrm{An}$ interim order ${ }^{65}$ may be granted, and after an enquiry, a final order may be granted against a respondent. ${ }^{66}$ The protection order may prohibit the respondent from committing any act of domestic violence; from entering a specified place; or from committing an act set out in the order. ${ }^{67}$ The warrant of arrest is issued simultaneously with the order, and brought into effect if the complainant reports that the respondent has breached any provision of the order. ${ }^{68}$ If he or she is found guilty of a contravention, then the court may convict the respondent and sentence him or her to a fine or a term of imprisonment. ${ }^{69}$

While the Act criminalizes the breach of an order, it does not create an offence of domestic violence. ${ }^{70}$ Where the offender commits an act that is recognized by the criminal law as a criminal offence, the victim can report the case to the police, and it may proceed to a criminal trial. ${ }^{71}$ It is submitted that, although the Act offers one form of protection to women who are the victims of domestic violence, it does not necessarily offer remedies to the problem. ${ }^{72}$ However, it must be acknowledged that, the Act is an indication of the seriousness and commitment which the South African government views domestic violence but it has failed to address the issue of domestic violence. This can be illustrated by the statistics in South Africa for 2012 below: ${ }^{73}$

- 1 in every 4 South African women or $25 \%$ of women in South Africa is assaulted by their boyfriend or husband every week.

- $43 \%$ of 159 women surveyed had experienced beating and marital rape.

- 1 in 5 women is beaten by her partner.

- In South Africa 1 in every 5 women is abused by her husband or partner.

- Prevalence of domestic violence against women was found to be $38 \%$ of which 1 in 4 , was perpetrated by the husband.

- The average age of girls who are sexually abused is 11 years of age.

These statistics do not include the brutal, savage, violent murder and rape of Thandiswa Qubuda of Grahamstown who was beaten and had her right ear slit on t January 20, 2013 attack. She was found partially undressed and unconscious in a neighbour's backyard, she never regained consciousness and died at the hospital. Six men were arrested for her murder after the attack and released on bail, the violent murder and rape of 17 year old Anene Booysen from Bredasdorp in the Western Cape on February 2, 2013 who was gang raped and mutilated at a construction site. Booysens managed to identify one of her attackers before she died in hospital.

Almost a week later, on February 14, 2013, paralympian and track athlete star, Oscar Pistorius shot dead his model girlfriend, Reeva Steenkamp through the bathroom door believing her to be an intruder. Pistorius has since been released on bail of R1 million and is currently on trial. A 17 year old mentally disabled girl from Soweto was gang raped to keep quiet.

Ivy Molefe of Mmabatho in the North West Province was reported missing by her husband after she never returned from work at the provincial department of finance on March 14, 2012. Police searched for her and also called clerics and traditional healers for assistance. Four men were arrested in April 2012 before one of them made a confession and pointed out where Molefe's body had been hidden. The four murderers had taken Molefe to a bank to draw money before killing her. They had also stolen her car. However, the four people including the husband have been convicted and jailed for the murder of Ivy. As the world was celebrating Women's day, a court charged a man accused of chopping up and

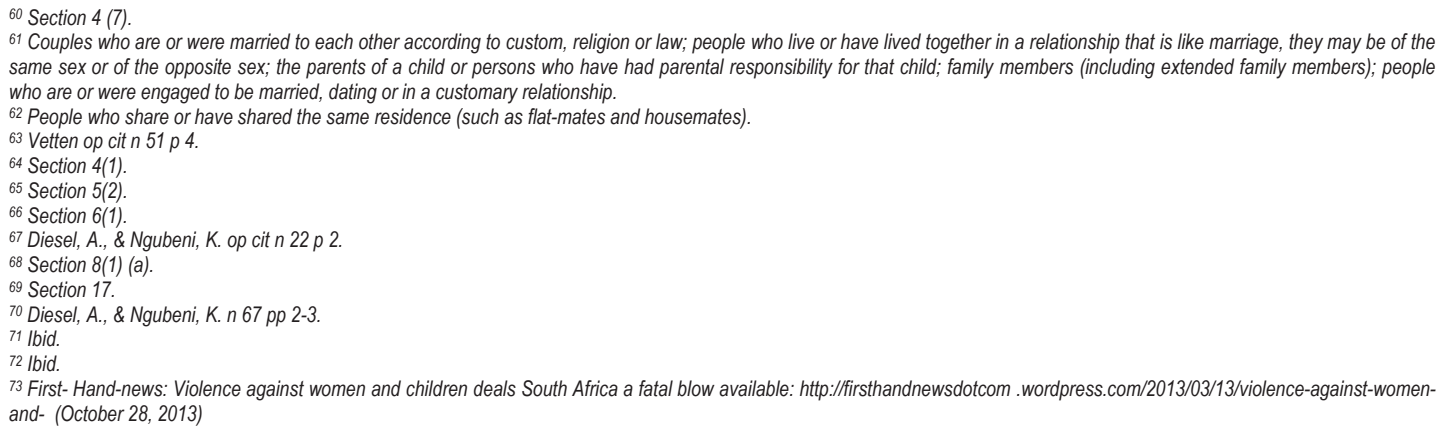

${ }^{61}$ Couples who are or were married to each other according to custom, religion or law; people who live or have lived together in a relationship that is like marriage, they may be of the same sex or of the opposite sex; the parents of a child or persons who have had parental responsibility for that child; family members (including extended family members); people who are or were engaged to be married, dating or in a customary relationship.

62 People who share or have shared the same residence (such as flat-mates and housemates).

63 Vetten op cit $n 51$ p 4.

64 Section 4(1).

65 Section 5(2).

66 Section 6(1).

${ }^{67}$ Diesel, A., \& Ngubeni, K. op cit $n 22$ p 2.

68 Section 8(1) (a).

${ }^{69}$ Section 17.

70 Diesel, A., \& Ngubeni, K. n 67 pp 2-3.

${ }^{71} \mathrm{lbid}$.

$72 \mathrm{lbid}$.

73 First- Hand-news: Violence against women and children deals South Africa a fatal blow available: http://firsthandnewsdotcom .wordpress.com/2013/03/13/violence-against-womenand- (October 28, 2013) 
beheading his wife with a machete; police arrested a 29-year-old accused of raping a 2-year-old toddler fighting for her life in the hospital; and police were investigating the rape of a 100-year-old great-grandmother. ${ }^{74}$

Children are also not sparred. The 2010/11 statistics from South African Police Service (SAPS) record a total of over 50000 crimes against children for 2010/11. More than half (52\%) of all reported crimes against children were sexual in nature, while sexual crimes accounted for only 19\% of crimes against adult women. ${ }^{75}$ On October 15, 2013 two year old Yonelisa Mali and her 3 year old cousin Zandile Mali were found dead in a communal toilet in Diepsloot. Five men were arrested and charged with kidnapping, raping and killing the two toddlers. There are many incidents of children been abused every day in South Africa. South African law offers specific protection for children who are victims of abuse. It also imposes severe penalties on offenders, particularly on those in the realm of child abuse. ${ }^{76}$ Not only does a wide range of statutory and common law offences therefore exists in terms of which a child abuser may be charged, but provision is made for children to be protected against legislation or executive or administrative action which may render them vulnerable to abuse. ${ }^{77}$ Children need to be protected from maltreatment, neglect, abuse and degradation, and the constitutional requirement that a child's best interests must be of paramount importance in every matter concerning the child apply in respect of domestic violence against children. ${ }^{78}$ Furthermore, South Africa has ratified the Convention on the Rights of the Child and must therefore comply with the obligations it imposes on state parties. ${ }^{79}$ They include protecting children from all forms of physical or mental violence, injury or abuse, neglect or negligent treatment, maltreatment or exploitation, including sexual abuse, while they are in the care of parents, legal guardians or any other person. ${ }^{80}$ However, it appears that in South Africa the focus as far as domestic violence is concerned, is more on the parties who are recognized as the direct victims of the abuse than the indirect victims. According to Divya, ${ }^{81}$ children who are not directly assaulted but who are 'merely' witnesses to acts of domestic abuse between adults in the home often remain the hidden victims of the abusive encounter. The reality is that a woman who lives with a child in the household and such child witnesses the abuse this child may suffer and endure harm merely from witnessing such an abuse that may be performed often by their father or a person who the mother is in an intimate relationship with. ${ }^{82}$ This situation violates section 28 (1) (b) and 28 (1) (d) of the Constitution which provides the protection of children's rights. ${ }^{83}$ However, government response is always quick to speak out and condemn the violence, yet it seems unable to prevent the scourge of domestic violence. There is a need to create a safe environment for women and children in South Africa. The 16 Days of Activism for No Violence Against Women and Children campaign which runs from 25 November (International Day for the Elimination of Violence Against Women) through to International Human Rights Day on 10 December is another government initiative which aims to challenge the perpetrators of violence to change their behavior, involve men in helping to eradicate violence, provide survivors with information on services and organisations that can help lessen the impact of violence on their lives. While the campaign runs only for 16 days each year, its objectives are reinforced by a year-long programme and a national plan to combat abuse. The government, business, civil society organisations, faithbased organisations and the media are all participating in the drive to increase awareness of the negative impact of violence and abuse on women and children. ${ }^{84}$ The enactment of the enactment of the Sexual Offenses and Related Matters Act ${ }^{85}$ is another step in the right direction on the part of government. The Act is administered under the Justice and Constitutional Development department. The purpose of the Act is to handle all legal aspects of or related sexual offences and crimes under one statute. It is hoped that with a proper training of all relevant stakeholders in the implementation of the Act, the situation will improve.

\footnotetext{
${ }^{74}$ Michelle, F. South Africa Violence against Women Rate Highest in the World available: http://www.huffingtonpost.com/ 2013/03/08/south-africa-violence-against-women( November 06, 2013)

75 Department of Social Development/ Department of Women, Children and People with Disabilities/ UNICEF (2012) http://www.dgmt-community.co.za/sites/dgmt/files /documents.v/.(November 28, 2013)

${ }^{76}$ Robinson, J. A. et al (2012) Introduction to Family Law $5^{\text {th }}$ ed 311

77 Ibid at 312.

78 Section 28 (2) of the Constitution.

${ }^{79}$ Cronje, D.S.P, \& Heaton, J. (2004) South African Family Law $2^{\text {nd }}$ edition Butterworths 254

${ }^{80} \mathrm{lbid}$.

${ }^{81}$ Signh, D. (2005) vol 6 (20) Children Who Witness Adult Domestic Violence part 2 - The Law, Legal Protection and the Role of Social Development and Child Welfare Agents: Child Abuse Research in South Africa, 36-43.

$82 \mathrm{lbid}$.

${ }^{83}$ Section 28(1) (b) provides that every child has the right to family care or parental care or to appropriate alternative care when removed from the family environment. Section 28(1)

(d) provides that every child has the right to be protected from maltreatment, neglect, abuse or degradation.

84 Weideman, M. 16 Days of Activism against abuse available: http://www.southafrica.info/services/rights/16days.htm. (October 21, 2013)

8532 of 2007.
} 


\section{The Role of the Police, Magistrates and the Courts in Domestic Violence Case}

\subsection{The South African Police Service (SAPS)}

The Act places obligations on judicial officers to empower and assist victims of domestic violence. ${ }^{86}$ There are only two courts that can enforce the Domestic Violence Act namely the Magistrate's Court or the Family Court. The South African Police Service holds the key to the successful implementation of the Act hence section 205 (3) of the Constitution deals with the objects of the police service. ${ }^{87}$

However, the DVA and its regulations do not have specific provisions in relation to the training of police officials. While it stipulates duties ${ }^{88}$, it does not specifically address training requirements for officials. Officials often receive short once-off training courses as opposed to continuous courses to keep them in touch and in tune with the challenges victims face as well as to maintain a comprehensive understanding of the Act.

To ensure that cases of domestic violence are taken seriously, the Act places an obligation on members of the South African Police Services (SAPS) to monitor, enforce and oversee the implementation of the requirements of the Act. The Act introduces statutory monitoring and oversight of police enforcement of the law. The police are required to explain to complainants that they are there to provide whatever assistance the circumstances require, which may include helping the complainant to find suitable shelter or obtain medical treatment. ${ }^{89} \mathrm{In}$ addition they should inform the complainant of her right both to apply for a protection order, as well as lay criminal charges. Where reasonably possible this information should be provided to the complainant in the form of notice. ${ }^{90}$ The notice also sets out the steps required to apply for a protection order, explains what the complainant should do in the event of a breach and sets out the type of relief or protection the complainant may request from the court. ${ }^{11}$ Where complainants cannot read the notice, police officers should read it to them in the language of their choice. ${ }^{92}$

Failure to comply with these obligations constitutes misconduct and the National Commissioner of the SAPS is required to submit six-monthly reports to Parliament detailing the number and nature of complaints against police for failing to adhere to these statutory obligations; ${ }^{93}$ disciplinary proceedings instituted; and steps taken as a result of recommendations made by the Independent Complaints Directorate (ICD). ${ }^{94}$ However, it was noted in 2005 that neither the National Police Commissioner nor the ICD had complied with their statutory duty to report to parliament every six months. ${ }^{95}$ At two bodies eventually submitted their first reports to the parliamentary committee in $2007 .{ }^{96} \mathrm{It}$ has also been submitted that, at the same time, the oversight bodies such as the ICD) appeared to have limited capacity to fulfill their functions. ${ }^{97}$

It is submitted that, police stations are struggling to deal with domestic violence complaints, with officers not understanding the law and failing to cope with paper work. ${ }^{98}$ The Civilian Secretariat for Police ${ }^{99}$ conducted 145 visits to police stations to check on how the DVA was being implemented and had also visited 155 police stations over six months, including three Johannesburg police stations which had previously been the focus of complainants by the public about the way police handled domestic violence complainants-Lenasia, South, Lenasia and Douglasdale police stations. ${ }^{100}$ The aim was to identify the gaps in the implementation and to develop recommendations for improved implementation. From all these visits and audits with different stakeholders ${ }^{101}$ many challenges were identified viz:

- members interviewed in various stations displayed very little knowledge of the DVA,'s implementation as

\footnotetext{
86 Smit, J., \& Nel, F. (2002) vol 15. An Evaluation of the Implementation of the Domestic Violence Act: What is happening in practice? Acta Criminologica 3.

${ }^{87}$ The objects of the police service are to prevent, combat and investigate crime, to maintain public order, to protect and secure the inhabitants of the Republic and their property, and to uphold and enforce the law.

${ }^{88}$ Section 2.

${ }^{89}$ Section 2 (a).

90 Section (2) (a-c).

${ }^{91} \mathrm{lbid}$.

92 Section 2 (b).

${ }_{93}$ Maatla a basadi- fighting domestic violence in South Africa available: http://maatlaabasadi.blogspot.com/ (June 11, 2013)

94 Section 18(4) (a). The ICD is a civilian oversight body established in terms of the 1995 South African Police Service Act. Theirs is primarily a monitoring and oversight function with the police obliged to institute disciplinary proceedings against recalcitrant officers, unless the ICD direct otherwise. The ICD is also required to submit six-monthly reports to parliament recording the number and nature of complaints received against the police, as well as the recommendations made about such complaints.

${ }_{95}$ Combrinck, H., \& Wakefield, L. Training for Police on the Domestic Violence Act, Research Report Available: http://repository. uwc.ac.za/xmlui/bitstream/handle/10566/209/com. (June 11, 2013)

${ }_{96} \mathrm{lbid}$.

97 Ibid.

98 Report by the Civilian Secretariat for Police Service (2013). This report looked at SAPS compliance with the Domestic Violence Act between April 2012 and September when the secretariat took over the monitoring role. The Civilian Secretariat for Police Services (the secretariat) was established in terms of section 208 of the Constitution of the Republic of South Africa and its responsibility is to exercise oversight over the South African Police Service. It operates under the direction of the Minister of Police.

99 lbid.

100 Flagan, L., Police don't understand Domestic Violence Act Available http://www.iol.co.za/news/crime-courts/police-don-t-understand-domestic-violence-ac (November 18,2013)

101 SAPS, National Provincial web sessions on legislation, joint DVA Forum, NGOs and academics.
} 
outlined in the SAPS National Instructions, 102

- The Secretariat discovered that certain documents which were kept by the SAPS did not have logos,

- police members and even station commanders did not know how to fill in the complaint registers, ${ }^{103}$

- police did not know where to refer complainants for help, as there are not enough shelters for victims, protection orders and warrants of arrest were not filled at most stations.

- Most importantly, the register for complaints against the police of non-compliance with domestic violence law was nonexistent in all the stations visited. According to the report, instead these complaints were logged in the disciplinary register as service delivery complaints not linked to domestic violence.

- Although half of the members interviewed had been trained, they lacked basic knowledge of the remedies available to complainants as set out in Form 1, and those trained reported that the training was academic with no practical examples.

- $\quad$ SAPS is supposed to have victim friendly rooms with private interviewing space for victims who came in to report DVA crimes. However, there were numerous cases found where they simply did not exist.

- In some of the police stations visited by the Secretariat, the police were themselves perpetrators of domestic violence. ${ }^{104}$

- The high rate of withdrawal of cases because victims were financially dependent on their abusers.

Legislative gaps were also identified, for example, the Department of Social Development is not obliged by the DVA to provide shelter to victims of domestic violence, and its counselling services in rural areas are non-existent, women ended up without real assistance. There was uncertainty over who must serve protection orders, and victims often ended up having to do so themselves which exposes them to further violence by their abusers Furthermore, according to the DVA, a complainant may apply for a protection order any time or any day. ${ }^{105}$ However, in practice, courts operated only during working hours and sometimes it can be difficult for magistrates who did not have resources to grant applications after hours. It has also been argued that other magistrates have indicated that the police rarely contacted them to issue urgent, after hours applications. ${ }^{106}$ The SAPS was also apparently unable to get the National Prosecuting Authority (NPA) or court personnel on stand-by, so often complainants had to wait until a Monday. The Act also failed to set out any clear time frame on service of protection orders and proof of service, mentioning that they should be served 'without delay'.

Although recommendations had been made to strengthen the oversight responsibilities of the Civilian Secretariat, one is still tempted to conclude that it would seem that all the role players are failing the victims of domestic violence. Many victims are not even aware of their right to apply for a protection order. There are many factors which affect the implementation of the DVA. Many women stay with the perpetrator of the abuse because they are economically dependent on the perpetrator or fear for their lives. ${ }^{107}$ Women in rural areas are even more disadvantaged in that to a certain extend they do not benefit from the provisions of the DVA and the state resources spent on ensuring its effective implementation. ${ }^{108}$ They face many challenges amongst others, linguistic problems, difficulty in understanding the procedures and the travelling distance to reach courts and the fact that generally have nor received training in customary law. ${ }^{109}$ It is submitted further that, the DVA can only be enforced in the Magistrate's Courts of Family Courts. ${ }^{110}$ There is no provision for traditional courts to issue protection orders whereas there are approximately 1500 customary courts in South Africa. ${ }^{111}$

\subsection{The role of the magistrates in domestic violence cases.}

The duties of the magistrate in domestic violence cases are set out both in the Domestic Violence Act and Regulations Under the Domestic Violence Act, $19988^{112}$ Broadly, the role of the magistrate in domestic violence cases is to: ${ }^{113}$

\footnotetext{
102 lbid.

103 There were 11850 members in the stations that the Civilian Secretariat for Police visited, but according to the report, less than half, that is, only 4308 members had received any training on the Domestic Violence Act. Some of the key areas in which members of the SAPS displayed lack of knowledge included the concluded the contents of Form 1, which set out the remedies available to complainants.

${ }^{104}$ According to the Secretariat, in total, there were 88 cases, broken down into:Eastern Cape: 07,Freestate: 10, Gauteng: 29, Kwazulu-Natal: 05, Mpumalanga: 09, North West: 12, Northern Cape: 05, Western Cape: 11.

105 Section 4 (5).

${ }^{106}$ Artz, L. (2003) Magistrates and the Domestic Violence Act: Issues of Interpretation, Institute of Criminology, University of Cape Town: South Africa 34.

107 Domingo, W. et al (2012) Law of Persons and the Family Pearson Education South Africa $1^{\text {st }}$ ed 447.

${ }_{108}$ Curran, E. \& Bonthuys, E. (2005) 21 Customary Law and Domestic Violence in Rural South African Communities South African Journal on Human Rights 607.

$109 \mathrm{Ibid}$.

${ }^{110}$ Curran \& Bonthuys op cit $n 110$.

111 Ibid.

112 Artz op cit $n 108$ at 9

113 lbid.
} 
- Issue ex parte interim protection orders if the court is satisfied that there is prima facie evidence that a respondent (the accused) has committed an act of domestic violence and undue hardship may be suffered by an applicant (complainant) if a protection order is not immediately issued. ${ }^{114}$

- Grant a final protection order in cases where the court is satisfied that proper service of the interim order with the return date to court has been served effected on the respondent and that the application contains prima facie evidence that the respondent has committed or is committing an act of domestic violence. ${ }^{115}$

It has been submitted that although magistrates were generally of the opinion that the Domestic violence Act is a progressive and useful piece of legislation, procedurally the DVA was seen as cumbersome. ${ }^{116}$ The positive legal duties on the police was considered necessary however, it was acknowledged that the independent monitoring systems within the criminal justice system was not sufficient to ensure performance. ${ }^{117}$ The issue of cramped courts, heavy caseloads and the fact that magistrates don't focus primarily on domestic violence cases, lack of specifically allocated resources to implement the Act in the way the legislature intended proved to be a hindrance. Furthermore, magistrates themselves are not adequately trained on the implementation of the DVA. ${ }^{118}$

\section{Conclusion and Recommendations}

Despite the South African government's ratification of various international agreements that condemn violence against women, as well as the national adoption of policies and appropriate legislation, there seem to be no significant change in curbing the prevalence of domestic violence. One may argue that on paper, the Act meets many Constitutional obligations and there is no doubt that the intentions of its drafters are clear. It is, however, impossible to give complete effect to these intentions in a system that is poorly resourced, overburdened and desperately in need of training. Domestic Violence Act imposes a duty on state officials to oversee application of the Act. ${ }^{119}$ Even though the Act was introduced to afford victims of abuse with maximum relief, one should keep in mind that there are a number of factors that influence the implementation of the Act with the result that the reach of the Act in the protection of those abused are severely limited. The challenges that affect the proper implementation of the Act and how these factors affect the victims of domestic violence are discussed broadly below.

\subsection{Access to justice by victims}

South Africa is burdened with the reality of a complex social context whereby most of the women victims are resident within rural areas compared to those who are in metropolitan areas. This poses even greater challenges to the effective implementation of legislation. ${ }^{120}$ There is no provision for traditional courts to issue protection orders when a complaint is being laid by a victim under customary law. ${ }^{121}$ This is an important omission given that a large number of people are subject to customary law and, therefore, research on the legal response to domestic violence would be incomplete if it ignored access to justice in rural areas and under customary law. ${ }^{122}$

Socio-cultural practice, linguistic and economic reasons may limit the abilities of many rural women to access the Magistrates Courts, while Family Courts function only in urban areas. ${ }^{123}$

\subsection{The influence of tradition}

South Africa's men from across the racial spectrum are raised to see themselves as superior to women and taught that men should be brave, strong and respected. ${ }^{124}$ With most men perceiving that women should submit to control by men, physical and sexual violence are used against women to demonstrate male power, and thus teach women 'their place', and to enforce it through punishment. ${ }^{125}$ As a result of these dominant ideas of manhood, violence against women

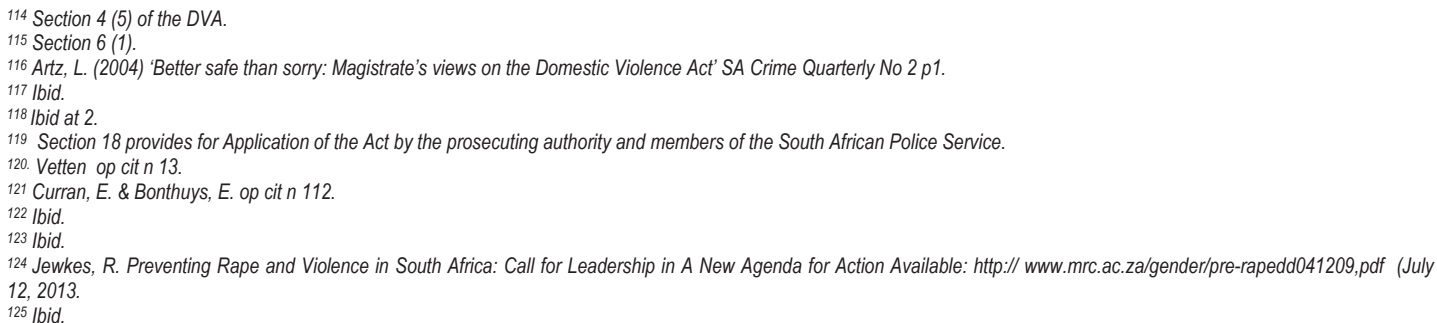


increases. From a historical point of view of view, there are indeed indications that in most societies women have been accorded a lower status than that of men. Before the Black Administrative Act was amended, there were certain provisions, which stipulated that a woman married under customary law was deemed a minor and her husband, her legal guardian. ${ }^{126}$ Bhe $v$ Magistrate Khayelitsha ${ }^{127}$ illustrates the dilemma facing African women as a result of the official customary law of succession. The man died, his father laid claim to the property. When the woman refused to give it up, the father and other relatives of the deceased repeatedly threatened her with violence and tried to evict her from the property. This case was subsequently heard before the Constitutional Court which declared the customary rules of succession unconstitutional. Van der Hoven ${ }^{128}$ refers to the cases were lobola payment contribute to the increase of women's vulnerability to domestic violence because payment is in cash and men sometimes justify their rights to abuse wives by claiming that they paid for them. However, it is submitted that there is a need to educate young boys from early childhood that women and girl children are not objects that they can own but rather their equals.

\subsection{Poverty, social inequality and dependence on the abuser}

One of the purposes of the Act is to afford greater protection to victims of abuse. This can only be achieved by enabling women to leave their abusive partner which often requires financial support. In most cases, the abused victim is financially dependent on the abusive partner. For example, in rural areas most women are unemployed and many of them remain in abusive marriages for economic reasons. This is despite the Act stating that withholding financial support from a woman may also qualify as economic abuse. There is also a clear indication of poor coordination and cooperation among all the role players that deals with domestic violence.

\section{Recommendations}

In order for the Act to be enforced on a daily basis for victims, specialized domestic violence courts should be established. Courts which will focus mainly on domestic violence that would be managed by a dedicated team of administrative personnel, judicial officers, police and social workers. ${ }^{129}$

- Police officials must be trained to enable them to make informed decisions that best protect victims of domestic violence and abuse. In order for police officials to be able to adequately inform victims of their rights in terms of the Act and to explain certain information, they need detailed understanding of the issues involved and an ability to put information across in a clear and simple manner. ${ }^{130}$

- Women must be empowered from an early age, they must be taught to stand against bad cultural practices or practices that undermine their human rights. Young women must be encouraged to study and be self-reliant as their dependency on men has often resulted in abuse.

- The justice system should establish programmes which will educate victims about the Act and their legal rights. This will include educating victims about the sort of protection available to them.

- School curriculum especially foundation phase (primary school) should incorporate domestic violence in lifeskills subjects.

- There is a need for a broader communication between the SAPS, NPA, Department of Justice and Constitutional Development, the Department of Social Development, Communities, NGO's and Faith based organisations need to coordinate their activities in trying to root out domestic violence from our society.

\section{References}

Currie, I., \& De Waal, J. (2005) The Bill of Rights Handbook $5^{\text {th }}$ ed Juta Cape Town

Currie, I., \& De Waal, J. (2005) The New Constitutional \& Administrative Law vol 1 Juta Cape Town

Cronje, D.S.P., \& Heaton, J. (2004) South African Family Law $2^{\text {nd }}$ ed Butterworths, Durban

Domingo, W. et al (2012) Law of Persons and the Family Person Education South Africa 1 ${ }^{\text {st }}$ ed

Robinson, J.A. et al (2010) Introduction to Family Law $5^{\text {th }}$ ed

\footnotetext{
126 Kruger op cit $n 47$ 152- 173.

1272004 (2) BCLR 27 (CC).

${ }^{128}$ Van de Hoven, A. (2001) vol 14 Domestic Violence in South Africa 2001 Acta Criminologica 5.

${ }^{129}$ Smit, J. \& Nel, F. op cit n.

${ }_{130}$ Marumoagae, C. (2011) The role of the police in fighting acts of domestic violence De Rebus 5.
} 


\section{Journal articles}

Artz, L. (2004) 'Better safe than sorry: Magistrate's views on the Domestic Violence Act' SA Crime Quartely No 2 p 1.

Artz, L. (2003) Magistrates and the Domestic Violence Act: Isues of Interpretation, Institute of Criminology, University of Cape Town: South Africa 34.

Curran, E. \& Bonthys, E. (2005) Customary Law and Domestic Violence in Rural South African Communities South African Journal on Human Rights 607.

Kruger, H.B. (2004) vol 29(1) Addressing Domestic Violence: To What extend does the law provide effective measures Journal of Juridical Science pp. 152-173.

Marumoagae, C. (2011) The role of the police in fighting acts of domestic violence De Rebus 5.

Smit, J. \& Nel, F. (2002) vol 15. An Evaluation of the Implementation of the Domestic Violence Act: What is happening in practice? Acta Criminologica 3.

Norvitz, T. (1996) The Prevention of Family Violence Act 1993, Law, Race, and Gender Research Unit, University of Cape Town

O 'Callaghan, E. (2011) Council of Europe: Case-Law of the European Court of Human Rights The International Survey of Family Law, 19.

Signh, D. (2005) vol 6 (20) Children Who Witness Domestic Violence part 2- The Law, Legal Protection and the Role of Social Development and Child Welfare Agents: Child Abuse Research in South Africa, pp. 36-43.

Van de Hoven, A. (2001) vol 14 Domestic Violence in South Africa Acta Criminologica 5.

\section{Case law}

South Africa

Bhe v Magistrate Khayelitsha 2004 (2) BCLR 27 (CC)

Carmichele v Minister of Safety and Security and Another 2001 (4) SA (CC); 2001 (10) BCLR 995 (CC).

Narodien v Andrews 2002 (3)_SA 500 (C).

S v Baloyi 2000 (1) BCLR 86 (CC),2000 (2) SA 425 CC; 2000 (1) SACR 81 CC.

$S$ v Chapman 1997 (3)SA 341 (SCA)

Van Eeden v Minister of Safety and Security (Women's Legal Centre Trust as Amicus Curiae 2003 (1) SA 389 (SCA).

International

Opuz v Turkey 2009 App no 33401/02, 9 September 2009.

\section{Legislation}

Constitution of the Republic of South Africa, 1996.

Domestic Violence Act 116 of 1998

Prevention of Family Violence Act 133 of 1993

\section{Internet sources}

Combrinck, H., \& Wakefield, L. Training for Police on the Domestic Violence Act, Research Report Available: http://repository.uwc.ac.za/xmlui/bitstream/handle/10566/209/com (June 11, 2013)

Curran, E. \& Bonthys, E. (2004) Customary law and Domestic Violence in Rural South Africa Available: http://www.csrvr.org.za/docs /crime/givingwomenvoice.pdf (July 4, 2013)

Department of Social Development/Department of Women, Children and People with Disabilities/UNICEF 2012 Available: http://www. dgmt-community.co.za/sites/dgmt/files/documents.v/. (November 28, 2013)

Diesel, A., \& Ngubane, K, Giving Women their voice and Restorative Justice in South Africa Available http://csvr.org.za/docs/crime/givingwomenvoice.pdf. (October 20, 2013)

Flagan, L. Police don't understand Domestic Violence Act Available: http://www.iol.co.za/news/crime-courts/police-dont-understanddomestic-violence-ac (November 18, 2013)

Factsheet South Africa; Official Statistics for 2012/13 Available: http://africacheck.org/...factsheet-SouthAfrica accessed (October 22, 2013)

First- Hand-news: Violence against women and children deals South Africa a fatal blow Available: http://firsthandnewsdotcom .wordpress.com/2013/03/13/violence-against-women-and- (October 28, 20130

Freeman, C. Four women killed by their partners ever day in South Africa Available: http://www.thesouthafrican.com/news/four-womenkilled-by -their-partners-every-day (October 20,2013)

Jewkes, R. Preventing Rape and Violence in South Africa: Call for Leadership in A New Agenda for Action Available:http://mrc.ac.za/gender/pre-rapedd041209.pdf (July 12, 2013) 
Maatla a basadi- fighting domestic violence in South Africa Available: http:// maatlaabasadi.blogspot.com/ (June 11, 2013)

Michelle, F. South Africa Violence against women Rate Highest in the world Available: http:// www.huffingtonpost.com/2013/03/08/southafrica-violence-against-women (November 6, 2013)

Mshungane, M. (2004) Domestic Violence Under indigenous Law- Any remedies? Available: http://www.reference.sabinet .co.za/epublication-article/magistrate.april (November 28, 2013)

Vetten, L. Addressing domestic violence in South Africa: Reflections on strategy and practice Available: http://www.un.org/womenwatch /daw/egm/vam-gp-2005/docs/experts/vetten.vaw.pd (October 28, 2013)

Weidemen,.E. 16 Days of Activism against abuse Available: http://www.southafrica.info/services/rights/16days.htm. (October 21, 2013)

\section{Reports and other Relevant Material}

Report by the Civilian Secretariat for Police Service (2013)

\section{International Instruments}

United Nations Convention on the Elimination of All Forms of Discrimination Against Women (1979)

United Nations Convention on the Rights of the Child (1989) 